Oliver Gassmann and Maximillian von Zedtwitz (1998)

\title{
ORGANIZATION OF INDUSTRIAL R\&D ON A GLOBAL SCALE
}

The final version of this manuscript is published in $R \& D$ Management, 28(3): 147161.

The final publication is available at www.onlinelibrary.wiley.com:

http://onlinelibrary.wiley.com/doi/10.1111/1467-9310.00092/pdf

DOI: $10.1111 / 1467-9310.00092$

http://dx.doi.org/ 10.1111/1467-9310.00092

Please note that differences between this manuscript and the final publication may exist. In case of questions, please contact the corresponding author as indicated below. 


\title{
Organization of Industrial R\&D on a Global Scale
}

\author{
Oliver Gassmann*, Maximilian von Zedtwitz**
}

* Corporate R\&D at Schindler Lifts Ltd., 6031 Ebikon/Lucerne, Switzerland, oliver_gassmann@ch.schindler.com, and

** Institute for Technology Management, University of St. Gallen, 9000 St. Gallen, Switzerland, maxi.zedtwitz@item.unisg.ch

\begin{abstract}
Although the globalization of industrial R\&D processes has increasingly attracted management scientists and considerable work on R\&D internationalization has been done since the 70 s, important problems in organizing geographically distributed R\&D sites have not yet been resolved. This analysis is based on 165 interviews in 31 technology-based multinationals from Switzerland, Germany, USA, and Japan conducted between 1994 and 1997. We describe the extent of R\&D internationalization, its key drivers and principal impediments. Two trends are identified: (i) a geographic concentration on leading technology centers, and (ii) a tightened coordination of R\&D units. Overlaying structures, superimposed to regional and functional structures, play a central role in overcoming current deficits in global R\&D management. Organizational constituents of this structure are technology offices (Schering), technology management as a competence center (Schindler), central project offices (IBM), central project management (Bayer), project oriented career development (Bosch), virtual project management departments (Roche), and cross-cultural job rotation (ATR).
\end{abstract}

\section{INTRODUCTION}

Knowledge creation processes of technology-based companies have become increasingly global. The pioneers of $R \& D$ internationalization are high-tech companies operating in small markets and with little R\&D resources in their home country, as it is the case for ABB, Novartis and Hoffmann-La Roche (Switzerland), Philips (Netherlands) or Ericsson (Sweden). As early as 1986, Dutch and Swiss companies had more laboratories outside their home countries than inside (Pearce and Singh, 1991). Between 1985 and 1993, overseas investment in R\&D by US firms increased three times faster as did domestic R\&D. In the US, overseas R\&D expenses reached $10 \%$ of overall R\&D investment, up from $6 \%$ in 1985 (National Science Board 1996: 4-44). In the same period, the share of majority-owned foreign affiliates' $R \& D$ in the US rose from $9 \%$ to over $15 \%$ (National Science Board 1996: 4-46). In 1991, Japanese multinational companies performed less than $5 \%$ of their R\&D abroad (Buderi 1991: 85), but the recent establishment of Japanese laboratories in Europe and the US increases the significance of Japanese-based global R\&D (see e.g. Dalton and Serapio, 1995). According to Buderi (1991), European companies performed about one third of their R\&D outside their home countries.

Literature on $R \& D$ internationalization has long focused on the economic and political perspective. Most research on this topic has taken place on a macro-economic or sectoral level (see Patel 1996, Papanastassiou and Pearce 1994; Beise, Belitz 1996, NIW et al. 1995; Amstad et al. 1996; Håkanson 1981). Management research has long neglected international R\&D (see Cheng and Bolon 1993: 3; 
Table 1. Technology-based companies in our research sample and principal R\&D sites

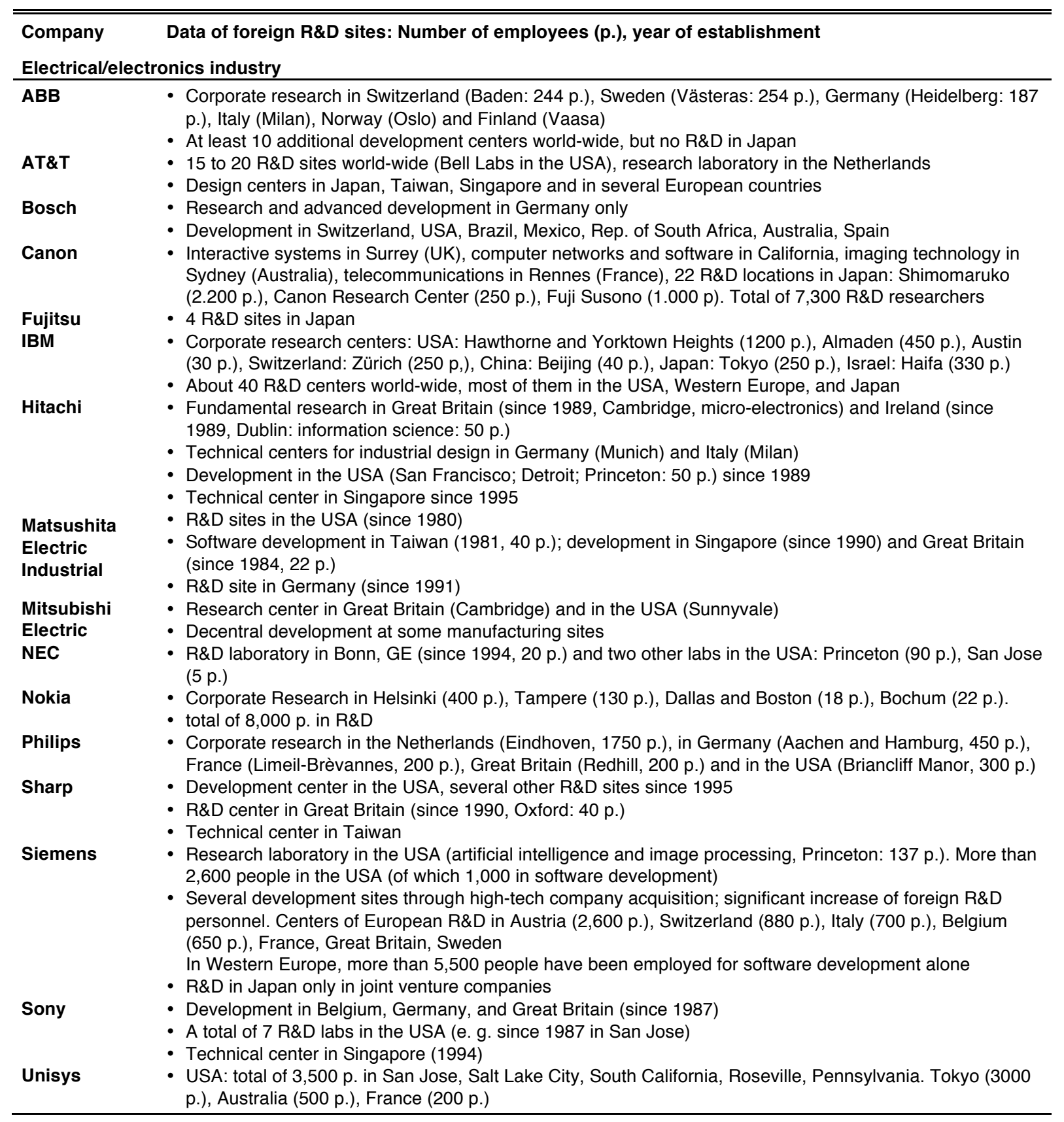

Granstrand et al. 1993: 414; Cantwell 1992: 94). A principal issue in $R \& D$ internationalization is the location decision, which has been studied by e.g. Brockhoff (1997), Pearson et al. (1993); Håkanson (1992); Gerpott (1991); Wortmann (1990); De Pay (1989) and Gassmann (1997a) on project level. Although this research has produced invaluable knowledge that immensely enhanced our understanding of the phenomenon per se, interviews with
R\&D managers have shown that a practical guiding framework for organizing international $R \& D$ is still missing.

In our paper we first summarize the motives and trends in $R \& D$ internationalization. We have found that many companies struggle with an inadequate $R \& D$ organization when attempting to draw on the potentials of global R\&D. In a globalizing world traditional $R \& D$ organization proves to be 
Table 1. (cont.) Technology-based companies in our research sample and principal R\&D sites



ineffective for many new challenges: R\&D directors must learn to manage an additional organizational level in order to ensure global R\&D efficiency. In particular, the geographical distribution of $R \& D$ exerts a significant influence on the company's overlaying organization structures. In a study of technology-intensive companies we selected state-of-the-art methods how industrial R\&D may be successfully organized on a global scale. Not surprisingly, the management and development of people is a central aspect in effectuating optimal use of overlaying structures. In this paper we focus on the structure that facilitates and enables the execution of projects and the effective exchange of knowledge and information. In the future, overlaying structures, which are superimposed and often independent from geographical or hierarchical structures, will become even more important.

\section{Research Sample}

Our research is mainly based on 165 semistructured interviews in 31 technologybased companies between 1994 and 1997. All companies are characterized by a high degree of internationality and operate in the following industries: electrical / electronics, automotive / turbines / heavy machinery, and chemicals / pharmaceuticals. We focused on companies that are pioneering the internationalization of their R\&D activities. Their home bases are in Europe (16), USA (5) and Japan (10).

Table 1 lists the main R\&D locations of companies in our research sample. The data for this research was gathered in personal interviews with principal representatives (R\&D directors and managers) of each company, following a semi-structured interview guideline. This data was complemented by desk research and feedback from our interview partners.

\section{TRENDS IN R\&D \\ INTERNATIONALIZATION}

\subsection{International $R \& D$ Locations}

Most of the analyzed companies perform a significant amount of R\&D abroad (Fig. 1). There is a strong indication for a correlation between technology intensity (R\&D expenditures per sales) and $R \& D$ internationalization (R\&D expenditures and personnel deployment abroad). Based on a classification scheme used by the Institute for System Research and Innovation in Karlsruhe, companies with an $R \& D$ ratio between 3.5 and $8.5 \%$ are considered as high-tech companies, while an $\mathrm{R} \& \mathrm{D}$ ratio above $8.5 \%$ indicates a science-based company. Our chart represents data on a corporate level. It neglects differences in $R \& D$ ratio and internationalization on individual business units but captures the shared use of $R \& D$ resources available to 
Table 1. (cont.) Technology-based companies in our research sample and principal R\&D sites

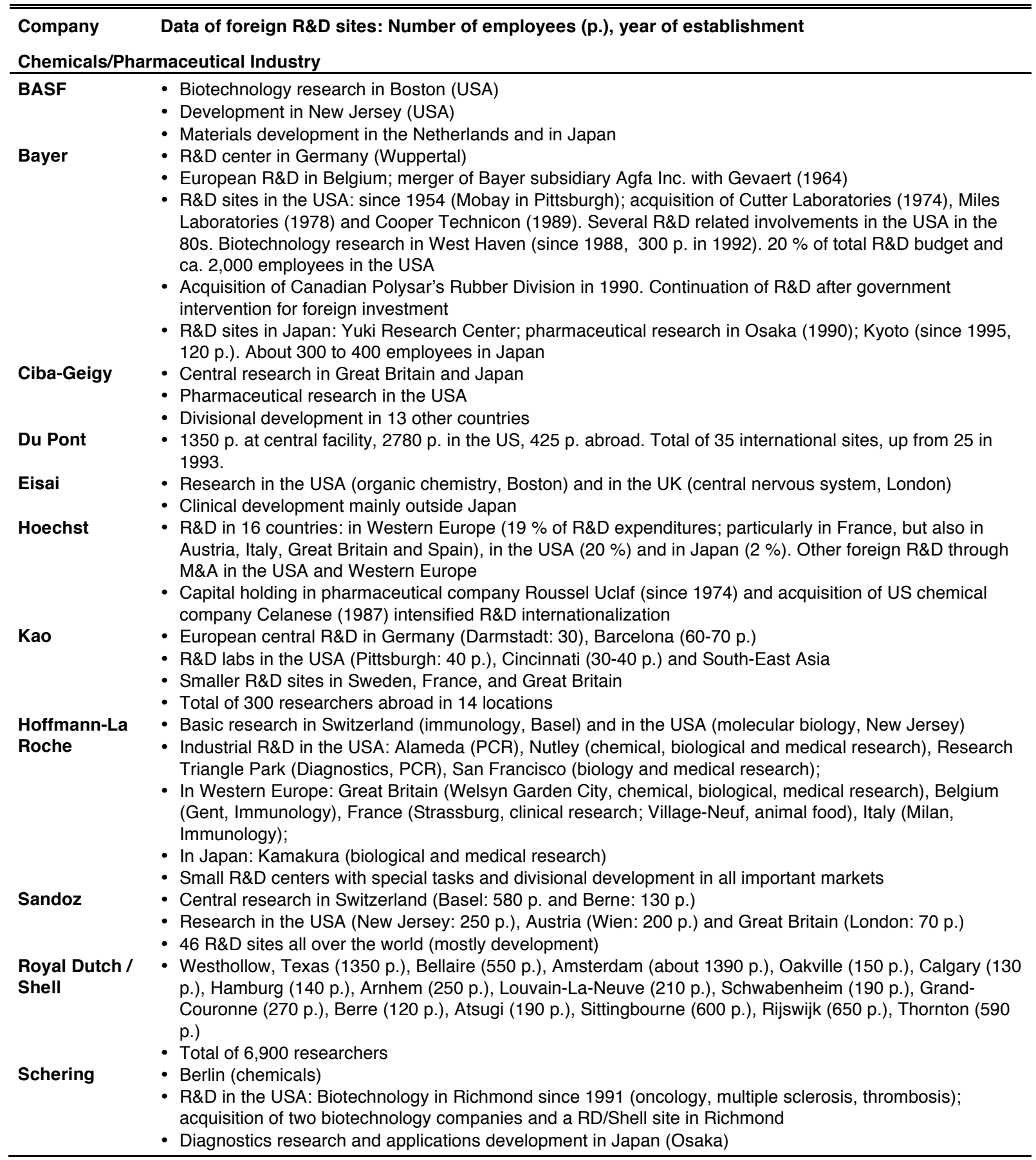

Source: Annual reports, company documents, interviews (1994-1997)

several business units. Consequently, some business units may have ratios different from their parent company as exhibited in Figure 1. As our intent was to demonstrate the overall significance of $R \& D$ internationalization in correlation with $R \& D$ intensity, we anticipated a certain variance per company, accepting the company's average figures as satisfactory indicators.
Technology-based companies are attracted to locate their R\&D activities at centers of technological excellence, i.e. regions characterized by a high rate of new technology output. The knowledge creation abroad is also intensified by the scarcity of resources at home. The location patterns we have found (see Table 1) indicate that 



Fig. 1. R\&D internationalization of technology-based companies (1994-1997)

knowledge-creating processes are asymmetrically distributed worldwide.

Based on this data we can confirm the continuing trend of R\&D internationalization as anticipated in Roberts' (1995) MIT study. Most of the surveyed companies have significantly increased their ratio of foreign $R \& D$ to total R\&D expenses. Many companies plan to further increase their number of international $\mathrm{R} \& \mathrm{D}$ sites in the next five to ten years (see also Gerybadze et al. 1997, Gerybadze and Reger 1997).

Although small and medium enterprises (SMEs) increasingly engage in international R\&D activities, R\&D internationalization of the 80 s and 90 s has largely been restricted to multinational companies (MNCs). Our research was thus focused on MNCs with a certain amount of international $R \& D$ experience. Technology-based companies from small countries have been leading this development. Swiss, Dutch and Belgian companies had more than $50 \%$ of its R\&D carried out outside their home country in as early as 1992 (see Gassmann 1997a: 53, and
Granstrand et al. 1993: 414). Until recently, most $R \& D$ was located in the triad regions of USA, Japan and Western Europe, but we observe a strong trend towards establishing development and design centers in SouthEast Asia. Market customization and access to local know-how are the main drivers for this trend, but there is a fine balance between a variety of determinants for and against R\&D internationalization.

\subsection{Factors Driving and Impeding $R \& D$ Internationalization}

Shorter product development cycles, global competition, increased customer expectations and technological risks have been major reasons to internationalize R\&D. While the traditional motivation for internationalizing corporate activities could be found in improving cash-flow and turnover quickly (international exporting and marketing) or reducing operating costs (e.g. setting up production in low-wage countries), short-term ROI objectives should 
not be followed when internationalizing R\&D.

Local markets, resources and synergy potentials are among the most cited drivers for R\&D internationalization. Synergies will become even more important over the next years because of the growth in mergers, acquisitions and cooperations.

The development of local products requires the early involvement of market and customer application know-how, which is more likely to be found in regional business units. Companies with local R\&D exhibit an inclination towards overemphasizing different local market specification in order to support local autonomy and independence from the parent company (image). Host country restrictions, such as local content requirements, tolls, import quota, and fulfillment of standards, can attract R\&D into key market countries (pull regulations). Reversely, constraining home country restrictions may induce companies to move R\&D abroad (push regulations).

The 90s have seen an effort of many large companies to consolidate their activities in order to realize synergy and coordination potential in international R\&D. If the corporate $R \& D$ network consists of competence centers (e.g. Roche, Schindler), transnational $R \& D$ projects are managed more easily, given that complementary competencies are provided locally. With increasing complementarity of resources, competencies, and knowledge bases, as well as the division of labor and specialization of work, synergy potential in R\&D projects carried out across several locations can be exploited.

Spill-over effects in know-how transfer occur when people from different locations become part of the same team. Informal know-how transfer by sharing experience between individuals is often superior to formal distribution of knowledge by means of handbooks, blueprints or patent rights. The establishment of a corporate-wide network rests heavily on those side-effects of informal contacts between members of different $R \& D$ sites. It is a major management challenge not only to exploit

Table 2. Drivers of R\&D internationalization

\begin{tabular}{|c|c|c|c|}
\hline Input-oriented & \multicolumn{2}{|c|}{ Output-oriented } & External \\
\hline $\begin{array}{l}\text { - Information and communication } \\
\text { - } \text { networks } \\
\text { - } \text { Insufficient home personnel } \\
\text { - Local pocket-of-innovation } \\
\text { - } \text { Lualified personnel abroad } \\
\text { - Local scientific community } \\
\text { - Tapping informal networks }\end{array}$ & \multicolumn{2}{|c|}{$\begin{array}{l}\text { - } \text { - Coutional and legal conditions } \\
\text { - Local economic and natural advantages } \\
\text { - Improving local image } \\
\text { - Adaptation to local production processes } \\
\text { - Customer-specific development } \\
\text { - Closeness to lead users } \\
\text { - Local values } \\
\text { - Market and customer proximity }\end{array}$} & $\begin{array}{ll}\text { - } & \text { Acquisition of parent } \\
\text { company, merger } \\
\text { - } & \text { Historic reasons } \\
\text { - } & \text { Peer pressure } \\
\text { - } & \text { Tax optimization }\end{array}$ \\
\hline \multicolumn{2}{|c|}{ Efficiency-oriented } & \multicolumn{2}{|c|}{ Politic / socio-cultural } \\
\hline \multicolumn{2}{|c|}{ 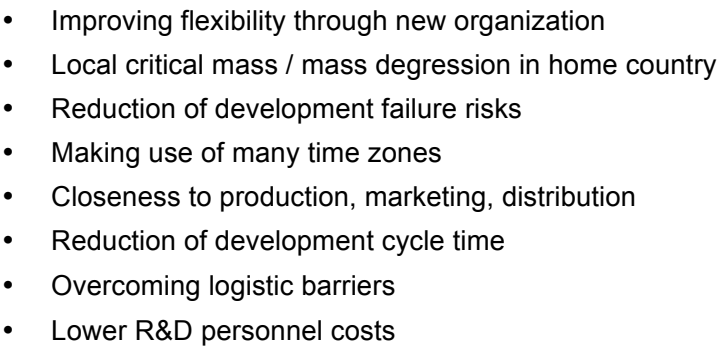 } & \multicolumn{2}{|c|}{$\begin{array}{l}\text { - Improvement of international patenting laws } \\
\text { - Overcoming protectionist barriers } \\
\text { - Local social and peaceful labor relations } \\
\text { - Local content } \\
\text { - Legal restrictions in home country } \\
\text { - Low home acceptance } \\
\text { - Subsidies }\end{array}$} \\
\hline
\end{tabular}

Sources: Beckmann and Fischer (1994), De Meyer and Mizushima (1989), Gassmann and von Zedtwitz (1996), Håkanson and Zander (1988), Carnegie Bosch Institute (1994), Krubasik and Schrader (1990), von Boehmer et al. (1992). 
Table 3. Determinants of R\&D centralization

\begin{tabular}{|c|c|}
\hline Reasons for central R\&D & Reasons against international R\&D \\
\hline $\begin{array}{l}\text { - Economies of scale } \\
\text { - Synergy effects } \\
\text { - Optimal career planning } \\
\text { - Minimal R\&D costs and development time } \\
\text { - No cases of „not-invented-here“ syndrome } \\
\text { - } \text { Allocation of technological competence to SBU } \\
\text { is simple } \\
\text { - Better control over basic research results } \\
\text { - Common R\&D culture }\end{array}$ &  \\
\hline
\end{tabular}

Sources: Behrmann and Fischer (1980), De Meyer and Mizushima (1989), Coombs and Richards (1993), Carnegie Bosch Institute (1994), von Boehmer et al. (1992), Beckmann and Fischer (1994), Gassmann and von Zedtwitz (1996).

informal networks for international R\&D activities, but also to foster the creation of new personal linkages between geographically dispersed R\&D units.

Table 2 lists the most important factors for conducting $R \& D$ not only in the home country. The reasons listed here both for and against R\&D internationalization were collected by literature analysis and during our research interviews. In general, we follow a classification scheme used by Beckmann and Fischer (1994). Inputoriented factors encompass drivers related to personnel, know-how and infrastructure. Proximity to markets and customers, collaborations and image are output- or product-oriented factors. Political and sociocultural factors such as local content rules, technology acceptance and public approval times, play an important role for locating R\&D abroad. Direct cost advantages (such as the often publicly discussed labor costs) rarely influence the internationalization of $\mathrm{R} \& \mathrm{D}$, but other efficiency-oriented factors such as costs of coordination and transfer, and critical laboratory size do have an impact on international R\&D organization.

In addition, external factors have a great impact on the dispersion of $R \& D$ sites. Many companies internationalize their $R \& D$ in the context of mergers and acquisitions (M\&As). The scope of all worldwide M\&As has doubled from 369 billion US-\$ in 1992 to an estimated 740 billion US- $\$$ in 1995 . In 1997, the volume of M\&As amounted to 1,630 billion US-\$ (Securities Data
Company 1998). About $70 \%$ of all acquisitions are based on a market-driven rationale (see Kutschker 1989: 12, Granstrand et al. 1993: 416, Håkanson and Nobel 1993: 402). M\&A activities also lead to a reduction of $\mathrm{R} \& \mathrm{D}$ locations. A redirection of strategy following a merger has led Novartis to actually reduce the number of central research laboratories by abandoning its former Ciba R\&D site in Takarazuka, Japan.

The case for R\&D internationalization is not unchallenged. Patel and Pavitt (1992) show by means of 1969 - 1986 patent data that research and development of core technologies were still highly domesticized in $1986 . \quad$ Reasons against internationalization are plenty (see Table 3 ). We divide our determinants against international $R \& D$ into a set of reasons explicitly preventing R\&D internationalization versus a set of reasons favoring centralization of R\&D. The individual items in this list are not necessarily mutually exclusive: A reason against internationalization may at the same time be a strong cause for centralization. Again, as in Table 2, some drivers may be more prevalent in some industries as they are in others.

Yet, more R\&D sites are established each year than existing $R \& D$ sites are dissolved (Howels 1990: 134). Divesting of acquired R\&D units is usually associated with high costs (e. g. pension funds payments, social plans) and has a negative impact on the 
work force morale. Furthermore, valuable technological competence with possibly high strategic potential may be lost (Pearson et al. 1993: 259).

International $R \& D$ has thus risen from a by-product of business internationalization to a quite important and far-reaching phenomenon. While this trend offers a great opportunity for global corporate learning, the underlying organization must be adapted for the new demands of international R\&D. Our study indicates that the organizational evolution towards a worldwide network of interconnected R\&D units is characterized by the establishment of overlaying structures of both the formal and informal kind. We shall briefly outline the trends towards more coordination and integration of formerly independent R\&D before introducing an organizational framework which we will use to describe how a company may support formal and informal means of transnational R\&D.

\subsection{Concentration on leading research centers and tight coordination}

In accordance with the results of Casson et al. (1992), we notice a trend towards the integrated R\&D network structure. This trend is characterized by two key developments: an increase of authority of foreign R\&D sites by assigning strategic roles and missions, and an integration of formerly loosely coordinated R\&D sites into a competence-based network. Once an integrated network structure is achieved a second trend may be observed: a concentration on leading high-tech regions, and a re-centralization of decision processes in few competence centers. General Motors and $\mathrm{ABB}$ are two examples for these trends.

General Motors (GM) tried to reduce $R \& D$ costs by tightening $R \& D$ coordination. Aiming at a global R\&D management without inefficient duplicate development, GM has started to restructure its world-wide R\&D network. It established four regional competence centers in order to centralize the development of new platforms. Based on these platforms, the development of variants is carried out locally. Besides the reduction of the number of variants, GM tries to implement global standards for 'invisible parts' and regional differentiation of 'visible parts'.

ABB successfully oversees 1,300 companies, 5,000 profit centers, 50 business units, 5 divisions and a great number of globally distributed and independent R\&D centers. The current dilemma with ABB's integrated corporate network has been formulated by CEO Barnevik: „ABB has three internal contradictions. We want to be global and local, big and small, decentralized with central reporting." In 1994, ABB tried to bring down the costs of running this network by tightening and centralizing the coordination of $R \& D$ activities. Corporate management was reduced to eight members drawn from all four product divisions. The reorganization strengthened the four product divisions noticeably and led to a recentralization towards fewer R\&D locations. Their autonomy is controlled by centralizing the important financial and information flows within top management.

Many companies have realized that the benefits of such a network structure exceed the high coordination costs if the network is properly managed. The economies of scale realized by advanced coordination of worldwide $R \& D$, a reduction of duplicate development, the realization of synergies, and a concentration on internal technology transfer across boundaries are the advantages of such a network. Summarizing the trends in the entire research sample, we observe six major trends that affect multinational technology companies:

\section{Increasing $R \& D$ internationalization:} The relative share of foreign $R \& D$ has dramatically risen in the last 15 years. Technology-based companies headquartered in small Western European countries have assumed a pioneering role, since their home country could not offer a sufficiently large resource pool for $R \& D$ nor a market of significant size. All of the surveyed 
companies have increased their R\&D expenditure to sales ratios between 1980 and 1995. They also set up new foreign R\&D laboratories and reinforced existing ones.

2. External orientation: Ethnocentric oriented companies such as Daimler, Nissan, Volvo, and Toyota increasingly participate in international centers of technology and know-how. Typically, this happens via strategic technology alliances, foreign manufacturing, and integration of local technical support in product development.

3. Listening post: A number of companies with centralized R\&D have begun to set up tightly controlled technology listening posts in centers of innovation. Japanese basic research laboratories in Europe and the USA are characteristic for this development.

4. Empowerment: Foreign $\mathrm{R} \& \mathrm{D}$ sites are assigned a strategic and active role in the R\&D network. The balance between autonomy and control shifts towards more competence for the local unit.

5. Integration: $\mathrm{R} \& \mathrm{D}$ units which have experienced little coordination will find themselves more integrated in the future. Corporate restructuring programs promote some units to centers-ofexcellence, which are responsible for a specific product group or technology field worldwide.

6. Recentralization: In heavily decentralized companies such as ABB, IBM and Hoechst we could observe a trend towards recentralization of $R \& D$ into a handful of leading centers. Inefficient locations are divested and existing competence centers more tightly controlled.

Companies that have grown by M\&A typically face the need of $R \& D$ integration (Gerpott 1994). Companies whose R\&D organizations have more steadily evolved follow a more sequential development of external orientation, listening post establishment and empowerment. In Gassmann (1997a and 1997b) and
Gassmann and von Zedtwitz (1998), we describe the drivers and trends of this organizational change in more detail. All of the surveyed companies could be observed to strive for a presence in a small number of leading innovation areas. Simultaneously, companies increasingly try to exploit possible synergies between decentral locations: Global efficiency becomes more important than local effectiveness.

\section{OVERlaying STRUCTURES FOR GLOBAL R\&D EFFICIENCY}

A discussion of the issues for global R\&D management includes the following arguments:

i. development of $R \& D$ and technical standards

ii. managing cultural diversity

iii. coordination of decentralized processes

iv. educating and training the global R\&D project manager

v. retention, integration and utilization of dispersed know-how.

In order to manage global processes it is helpful to understand the four levels of structure in international R\&D organizations (see also von Zedtwitz 1998). The regional and hierarchical structures are the foundation for transnational organizations, being simultaneously responsible for many barriers in global R\&D management. While these two structures have been inappropriate to deal with the here listed issues of global R\&D management effectively, overlaying and informal structures can help to overcome these barriers. We will see that solutions often evolve naturally if implemented in a superimposed, overlaying structure (Fig. 2).

We define the overlaying structure as the sum of all corporate mechanisms and procedures (such as cross-functional project teams) that do not fit into the general hierarchical line structure. Due to the rising demands on flexibility and dynamics in the company, this overlaying structure becomes increasingly important. The overlaying structure affects the creation and 


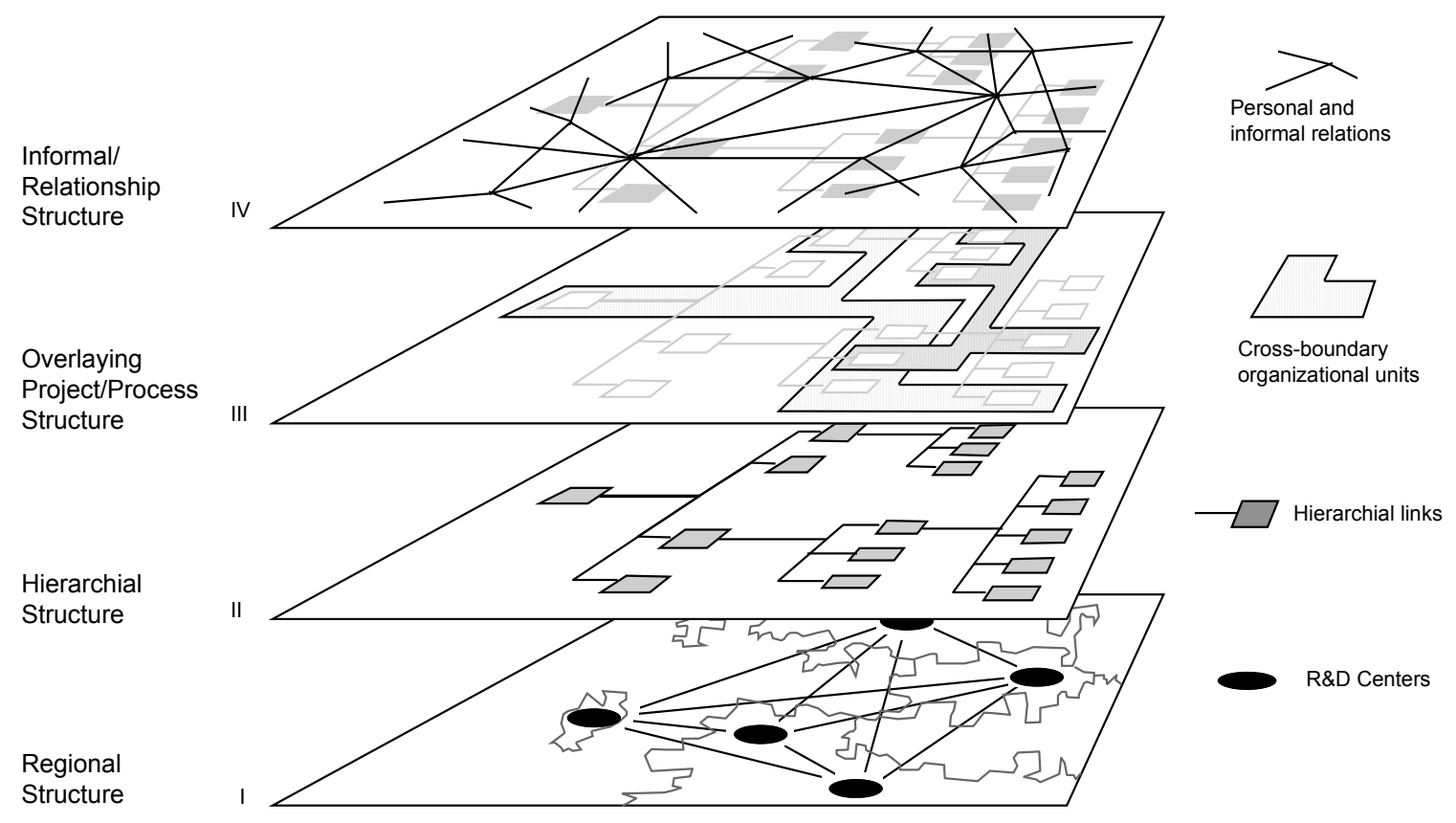

Fig. 2. Four levels of structure in international organizations

sustainability of an informal network encompassing relations and linkages both within and outside the company. Since this informal network structure powerfully transcends the entire organization, we expect great potentials to be exploited by managing this network structure more deliberately.

The idea of viewing an organization as a set of interlinked structures is not new. On the one hand, our model is related to the hypertext organization of Nonaka and Takeuchi (1995: 166-171), which is based on a Japanese publication by Nonaka and Konno in 1993. Nonaka and Takeuchi's hypertext organization is consisted of a business-system layer, a project-team layer, and a knowledge-base layer, and is considered a dynamic synthesis of both the bureaucratic structure and the hierarchyspanning task force. On the other hand, Schoonhoven and Jelinek (1990) introduce the concept of a quasi-formal structure. This intermediary structure is between a formal structure defined as subunits, positions, and reporting relationships and an informal structure consisting of unsanctioned patterns of interaction devised around social and task requirements the formal structure failed to take into account.

Our model puts more emphasis on the informal structure and introduces the regional structure as a major determinant for the overall organization. In the following we will concentrate on some important elements of the linkages from the overlaying structure to the hierarchical and to the informal structure. These elements are technology offices, technology management competence centers, virtual project management pools, international job rotation schemes, project offices, and project manager career planning.

\subsection{Schering's Technology Office}

The purpose of the technology office is to seek new and relevant information and to distribute it within the company. Information is researched upon request or provided internally when deemed relevant. The technology head office of Schering is located in Berlin, Germany (ten people), with an additional six people in Richmond, USA and four more in Osaka, Japan. The office functions as the company's ,eye and ear". In this role, it stays in close contact with the scientific community, organizes 
seminars and conferences, and looks after the diffusion of critical information to Schering's researchers. The personal and often informal contacts are a very important element to the success of the technology office, which is often forgotten when operating in network-like structures.

If $\mathrm{R} \& \mathrm{D}$ must be outsourced due to time constraints or insufficient internal knowhow, the office initiates contracts with external R\&D partners. In this case, the respective units or departments will contact the office and state the internal deficit and its request for outsourcing. The office then initiates a search process in order to find the required knowledge. Forecasting, evaluation and distribution of global available technology is one of the main task of the office. In summary, the technology office relieves researchers from many administrative and procedural chores, while supporting them in their core research activities.

\subsection{Schindler's Technology Management Competence Center}

Technology management should not be seen as a one-time project but rather as an ongoing process. Schindler therefore established technology management as a competence center. This center combines two traditional departments of Advanced Development (R\&D-AD) and Competitor Technical Observation (CTO), along with what was known as strategic technology management. The mission of Schindler's TM is ,the integrated management of new technologies for the maximum benefit of the Schindler Corporation." More precisely, it is responsible for the tasks given in Figure 3 and explained subsequently.

In advanced development, Schindler's TM aims at quantum leap developments in elevators through radical new approaches. New product concepts are defined and studies show the feasibility of such concepts. Advanced development is undertaken in very close cooperation with universities and external technology leaders in clearly defined areas. According to the core competence philosophy, Schindler is increasingly engaged in strategic technology alliances with suppliers who are technology leaders in their fields.

Technology and industry monitoring promotes systematic scanning and evaluation of new technologies which arise in other industries. These are evaluated in

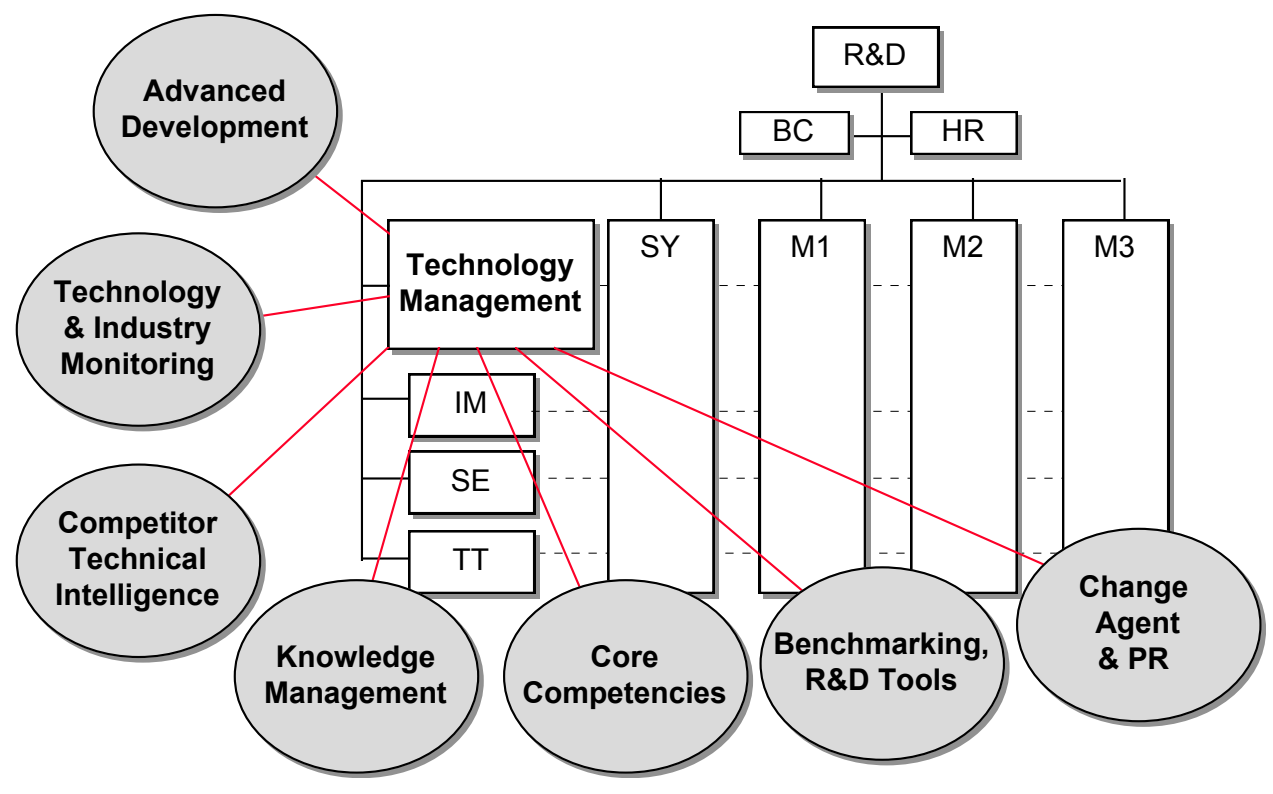

Fig. 3. Technology Management as a new competence center at Schindler Lifts 
terms of their applicability to elevators and escalators.

By means of competitor technical intelligence, Schindler's TM identifies technological activities of competitors. Socalled ,weak signals“ are identified with a variety of instruments based on e. g. patent analysis and publications.

Knowledge management optimizes information flow and the knowledge base of people. The goal is the development of the company's R\&D towards organizational learning. Several state-of-the-art methods and instruments such as knowledge maps, who-is-who lists and gatekeeper meetings are used in order to make knowledge management operational. This means that gatekeepers in R\&D teams must be identified and brought together in interdisciplinary technology fora.

Schindler's TM is responsible for updating and developing technical core competencies and technology portfolios in close cooperation with development centers. Schindler's TM also promotes the implementation of core competencies in the $R \& D$ organization and the development of skills in accordance with the human resource department.

By engaging in benchmarking, Schindler's R\&D compares itself with worldclass $R \& D$ in leading technologybased companies. Learning from ,best practice" across industries is promoted, in order to improve its R\&D organization, processes and tools. This also includes the implementation of the "lessons learned“".

Internally, Schindler's TM acts as a change agent to open the mind of every R\&D employee: According to 3M's model, every employee should think about new technologies and radical innovations for some part of his time. Externally, Schindler's TM takes care of R\&D public relations for attracting the best graduates from universities. Through contacts with universities and scientific publications, Schindler wants to be clearly identified as a technology leader in its field.
The team at the technology management competence center is highly skilled and very interdisciplinary. Building on their multicultural background (Swiss, French, German, Egypt, Chinese and Malaysian), these people reinforce Schindler's R\&D with new technologies, radically new concepts, state-of-the-art methods and R\&D tools. Schindler's competence center combines aspects of Schering's technology office with the integration of advanced development, listening post and analysis activities.

\subsection{Central Project Management}

Learning processes that span several locations are more complex than sporadic exchange of information and experience during a single project. In order to institutionalize and support these processes, a coordination office is required. This office ensures the continued information flow between all nodes of the R\&D network.

A corporate office called Central Project Management maintains this role at Bayer. This office provides $R \& D$ units with standardized project management instruments such as project manuals, development guides, IS support, and project management systems. If development is to be carried out routinely, ,standard operating procedures" become very important. Coordinating decentralized R\&D procedures and information flows is the main purpose of this project management unit.

IBM's solution is similar: For the coordination of decentralized VSE (Virtual Storage Extended) system development, IBM's project office plays a central role. A total of 20 components of the VSE system is needed to be coordinated, controlled and managed. In teams of two, each member of the office is responsible for a new release of the system. The number of members fluctuates in accordance with the number of projects assigned to the office. Among the tasks they deal with are the collection of requirements and specifications for a VSE release, the technical evaluation of project ideas, technical systems design, project 
controlling and coordination, project documentation, and VSE product planning.

Experienced senior advisory programmers screen, evaluate and refurbish new project ideas and proposals, eventually putting together a formal project proposal. All requirements are listed and prioritized. If a completely new project idea comes up, the office finds out which parts may be developed by the original proponent and which parts may be contracted to other R\&D sites (Fig. 4).

Project supervision and coordination requires a worldwide integration of all VSE development projects with respect to deadlines, milestones and project targets. After long years of experience, this process has been widely routinized by now. Nevertheless, the complexity of the task is enormous: The number of technical interfaces between different R\&D sites and the incorporation of previous project results require close attention.

The management of program interfaces is decentralized and self-regulating. A 'workbook' includes all specifications of the new VSE system and design change requests. The project office freezes the specifications once a certain milestone (or checkpoint) has been reached, as incongruent interfaces lead to high adaptation costs in later stages of development. Apart from the interfaces, the office also specifies when a certain program module has to be delivered.

Every project member has access to the project status document. This document is regularly updated by the office and serves as an information tool for identifying if a milestone has been reached and when the project may move into another phase. The project office also coordinates the development of national language versions of the VSE operating system. The English original is transferred to local $R \& D$ sites in the respective countries and translated into Japanese, German, and Spanish. In short, operative management of project schedules and technical interfaces in highly standardized development processes is the main task of IBM's project office.

\subsection{Cross-cultural Job Rotation}

Some companies are particularly good at internalizing external know how through

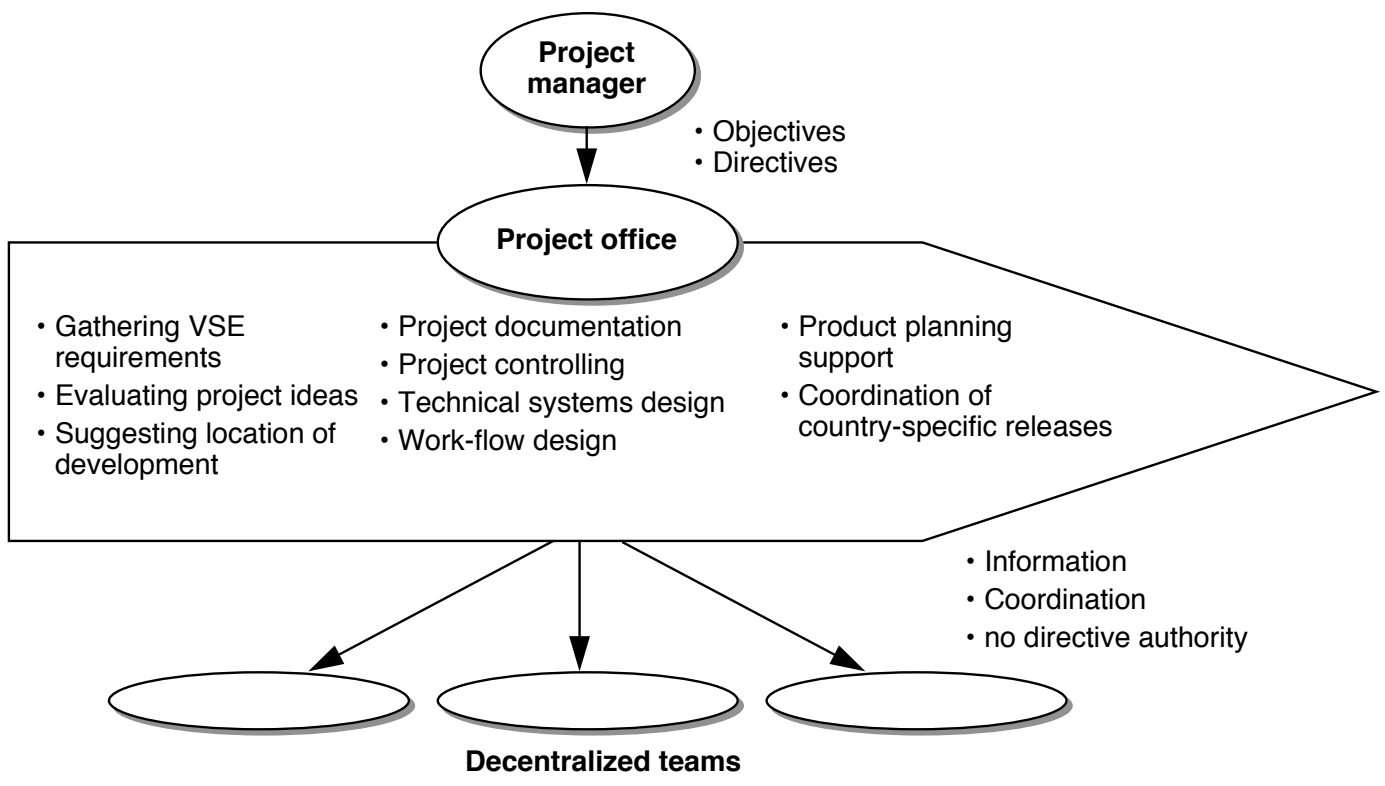

Fig. 4. The tasks of the VSE-Project-office at IBM 
hosting visiting researchers. This is especially true for those companies without overseas R\&D sites: Hosting foreign researchers and engineers in the parent company can be a major source of innovation. If the company has already established overseas $R \& D$, then visiting researchers can also be $R \& D$ members of another unit of the same company who have been sent abroad in order to learn about local research. Such visiting researchers are often assigned to collaboration projects that are funded by a business unit.

The Advanced Telecommunication Research Laboratories (ATR) - a Japanese basic research company - has recognized the importance of foreign input and established intensive relations with overseas research communities. Research projects are defined based on the competence and interest of new researchers, as long as the projects fit in the overall research program. A large number of foreign researchers work in mixed teams with Japanese scientists, but all of $R \& D$ management remains in Japanese hands. ATR employs about 50 invited foreign researchers for periods from one month up to several years, while some of the foreign researchers hold long-term job contracts. For instance, the ATR Human Information Processing Laboratory employed a total of 48 Japanese researchers and 35 foreign researchers in 1994. The majority of the Japanese researchers come from over 40 supporting companies and generally stay for three years before they return to their parent companies. This resulted in about 800 Japanese researchers and about 400 international researchers for the past ten years. ATR researchers produce a high amount of internationally coauthored articles. Furthermore, collaborations spin off after the foreign researcher has been transferred back to his home country. Thus, although entirely domestically organized, ATR is a highly internationalized company.

Hicks et al. (1994) found that most of the Japanese companies in the JPC (1990) sample of 149 firms employed no foreign researchers at all. $90 \%$ of the remaining companies employed less than ten foreign researchers. Because the international rotation of scientists and engineers is a quick and economical way of learning about external and foreign R\&D (de Meyer 1992), it is often a first step towards establishing a global R\&D network. Several Japanese companies which we interviewed currently pursue this approach to globalization. For instance, Nippon Steel set up a „Visiting Researcher Program" with the aim to activate $R \& D$ by introducing expert researchers worldwide and to promote a stimulative R\&D environment. Nippon Steel has accepted over 70 researchers in ten years, sending eleven researchers abroad for study annually. Similarly, the HIVIPS program introduced by Hitachi in 1984 was devised to realize synergy for innovation through heterogeneous cross-cultural interaction. This program is now seen as a major device for internal R\&D globalization at Hitachi (Kuwahara 1998).

Although similar programs are undertaken in other companies, the extent of international personnel exchange remains limited. Thus the Japanese corporate research workforce is mainly staffed by Japanese (Hicks et al. 1994), and can not be compared in diversity with its American or European counterparts.

Because earlier and later stages of $R \& D$ are often performed in different locations, the transfer of technology and know-how crosses not only organizational but also geographical distances. The Japanese chemical company Kao conducted an 18month-development project of hair cosmetics treatment. While such projects had been predominantly carried out in Japan, local adaptation for culture, different treatment styles, and physiological differences required the integration of $R \& D$ close to the eventual customer. While concept development and advanced research took place in Tokyo, much of the actual product development was carried out in regional $R \& D$ centers. Figure 5 depicts this concept in an example of hair treatment development in Tokyo and Darmstadt. 


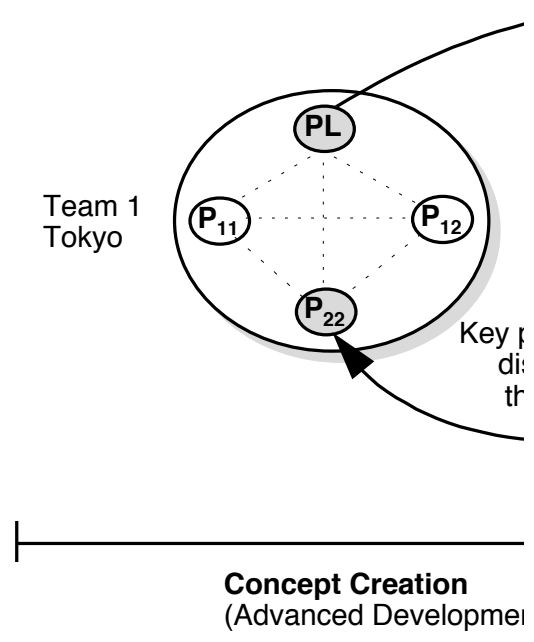

Fig. 5. Personnel exchange at Kao

Know-how between Japanese advanced development and German development was transferred by mutual personnel exchange. During the concept phase, a German scientist was sent to Tokyo to be part of the concept creation in the local project team. During the development phase in Darmstadt, the Japanese project manager supported the German team for two months. In this case, personnel continuity ensured technology and know-how transfer.

The main objective to exchange or invite researchers is manifold. The cross-cultural rotation supports the construction of a professional network, fosters creativity, raises an awareness for cultural differences, and ensures transnational project continuity and efficiency.

\subsection{Virtual Project Management Pools}

International $\mathrm{R} \& \mathrm{D}$ processes result in new challenges for human resource management.
International recruiting, administration and development of R\&D managers and scientists is not restricted to one location anymore but must be coordinated on a global scale. Especially the management of a project manager's career is a challenge that is rarely satisfactorily addressed.

Although personnel development in functional and line management is highly developed in many companies, it appears problematic to identify and systematically develop a pool of $\mathrm{R} \& \mathrm{D}$ project managers. Typically, qualified potential project managers are not recognized as such and miss chances for their own career development (see also Domsch 1993: 163). On a corporate level this leads to inefficient human resource allocation and suboptimal individual career planning. One of the most important aspects of personnel development is therefore the increasing support for „special design“ project manager careers outside the conventional line promotion. Human resource departments thus concentrate on financial incentives, formal recognition of project managers, and providing explicitly individual career springboards.

Bosch has set particular emphasis on the development and support of dual career ladders in its $R \& D$ project manager career planning. Based on an incentive scheme, successful project managers are assigned to larger projects after termination of their former projects, thus enabling them to rise in the ranks. Usually, they start with projects in component development or subprojects. Subsequently, they may assume tasks with more responsibility, more strategic orientation, and increased degree of complexity and internationalization. 
The systematic promotion of human resource development strategies may be succeeded by a specialized project management department (Fig. 6). HoffmannLa Roche's Pharma Division established a department called „International Project Management" which coordinates a resource pool of about 50 project managers for all R\&D projects worldwide. This department consumes about $30 \%$ of the pharmaceutical R\&D expenditures, having highly strategic importance for the innovative potential in this business.

Every project manager is fully assigned to this geographically decentralized department. The director of this ,virtual“ resource pool assigns his people as managers to projects also as part of a global program to ensure standards in quality and project procedures. Upon completion of his project, a project manager is returned to the resource pool. As there are more projects in the pipeline as potential projects managers available, he is immediately reassigned to a new project.

Since this relative new department reports directly to the Corporate Board, the internal political position of $R \& D$ project managers has been improved recently. Furthermore, the first director of the „International Project Management Department" was the wife of the then R\&D director, which increased the significance of the department. The establishment of a project manager pool is a clear signal for empowering and developing one of the scarcest competitive resources, hands-on operative management with long-term perspectives. Roche thus manages to retain much of the valuable procedural know-how to conduct and lead international projects not only inside the company, but also in a

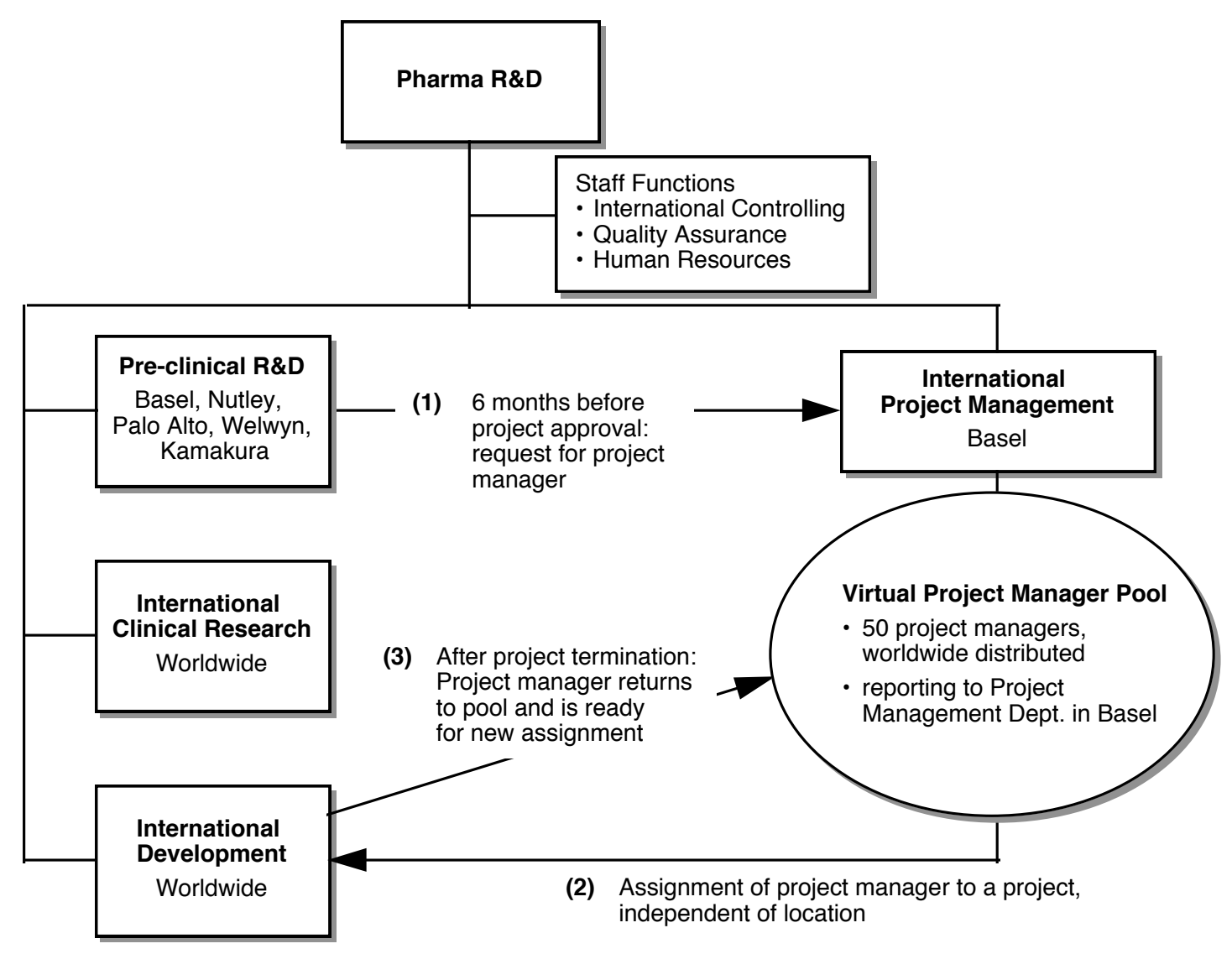

Fig. 6. Project management department as a virtual project management pool at Roche 
position where it can be reapplied when needed.

The director of the „International Project Management Department" is also in the International Project Committee, which decides over the roughly 60 global R\&D projects at Roche Pharma. The director assumes a role as interpreter or liaison between project managers and top management, thus representing the interests of international project management at Roche. This virtual pool promotes the project management idea: Experienced project managers are dispersed around the world and wander from project to project no matter where the project will be conducted. This virtual pool is more than just a international matrix organization as it expands and shrinks responding to the requirements of the international development centers.

\section{Conclusions}

The internationalization of $\mathrm{R} \& \mathrm{D}$ remains a key management challenge for the next years. Technology-based companies will continue to disperse their $\mathrm{R} \& \mathrm{D}$ activities around the world. Our research indicates a trend towards a concentration on leading high-tech areas and a tendency to tighten the coordination of international R\&D activities in competence centers.

The conventional organization of firms is inadequate for the requirements of modern global R\&D because it is constrained by hierarchical and regional barriers. New organizational forms must come to the rescue. Among those requirements are the development of managerial and technical standards in R\&D, managing cultural diversity, coordination of decentralized processes, educating and training the global $\mathrm{R} \& \mathrm{D}$ project manager, and the use and integration of dispersed know-how.

An overlaying structure presents a platform on which these requirements can be directly addressed. We have found and described a number of organization forms that successfully respond to above mentioned issues in global R\&D.
The institutionalization of technology management as a competence center at Schindler is an excellent example for an overlaying strcuture implemented on regional and functional structures. The management of new technologies is facilitated by integrating advanced development, competitor technical observation, and strategic technology management.

Project offices are suitable for highly routinized, incremental innovation projects, characterized by clearly defined responsibilities. In the IBM example, this is the case in the development of a new software package release. A central project management as found at Bayer ensures common standards which help reduce the complexity associated with decentralized $\mathrm{R} \& \mathrm{D}$ processes. This is done by providing coordination and a common IT infrastructure.

The practice of exchanging researchers or sending scientists abroad is an excellent source of new ideas and fosters creativity for all involved. Personal linkages are formed, and mutual trust and understanding not only increases the cultural awareness of the individual and his parent company, but also expedites interlocal project execution (e.g. around-the-clock research) and reduces the risk of NIH-syndromes. Companies use personnel transfer as a very efficient knowledge-management tool especially in the pre-competitive phases of the $R \& D$ process. If the company has no foreign $R \& D$ sites, it can resort to inviting external scientists and offer them excellent research and collaboration conditions in their home base.

Virtual project management pools like the one at Roche ensure professionalism and quality of project execution. Highly trained and motivated project managers are an incredible asset for a company depending on the success of each of their R\&D projects. It is the project manager and not the $R \& D$ engineers who should control the innovation process. Access to external know-how as well as the dissemination of internal 
knowledge is supported by a technology office serving as ,the eye and ear" of the company. No company in a knowledge- or science-intensive industry can afford to neglect the search for external information especially in the early and exploratory stages of technology development.

Organizing industrial R\&D for global efficiency is an often neglected task in corporate management. Our research has shown that integrated R\&D networks which are based on the core competencies of its R\&D units are an appropriate solution for many multinational technology firms. The described overlaying structures are part of the glue that holds the network units together, improving efficiency and effectiveness of global R\&D.

\section{ACKNOWLEDGMENTS}

We would like to thank numerous interview partners who have spend their time to share valuable information with us. Many of them have helped to correct errors in the company data. Nonetheless, the views presented in this paper are the sole responsibility of the authors. We are also indebted to Ursula Koners, Gregory Huber, and two anonymous referees for their insightful comments on earlier drafts of this paper.

\section{REFERENCES}

Amstad, M.; Arvanitis, S.; Hollenstein, H. (1996): Wie innovativ ist die Schweizer Industrie im internationalen Vergleich?, in: Gassmann, O.; von Zedtwitz, M. (Eds.): Internationales Innovationsmanagement. München: Vahlen, 231258

Beckmann, C.; Fischer, J. (1994): Einflußfaktoren auf die Internationalisierung von Forschung und Entwicklung in der Chemischen und Pharmazeutischen Industrie, in: Zeitschrift für Betriebswirtschaftliche Forschung 46, 7/8, 630-657

Behrmann, J. N.; Fischer, W. A. (1980): Transnational Corporations: Market Orientations and R\&D Abroad, in: Columbia Journal of World Business 15, 3, 55-59

Beise, M.; Belitz, H. (1996): Internationalisierung von $\mathrm{F} \& \mathrm{E}$ multinationaler Unternehmen in Deutschland, in: Gassmann, O.; von Zedtwitz, M. (Eds.): Internationales Innovationsmanagement. München: Vahlen, 215-230
Carnegie Bosch Institute (1994): Managing International Research and Development, Working Paper 94-8, International Executive Forum of the Carnegie Bosch Institute, Pittsburgh, 1993

Brockhoff, K. (1997): Industrial Research for Future Competitiveness. Heidelberg, Berlin, New York: Springer

Buderi, R; Weber, J.; Hoots, C.; Neff, R. (1991): A Tighter Focus for R\&D, in: Business Week of 2. Dec. 1991, 80-84

Cantwell, J. (1992): The Internationalisation of Technological Activity and its Implications for Competitivness, in: Granstrand, O.; Håkanson, L.; Sjölander, S. (Eds.): Technology Management and International Business: Internationalization of $R \& D$ and Technology. Chichester: Wiley, 75-95

Casson, M.; Pearce, R. D.; Singh, S. (1992): Business Culture and International Technology: Research Managers' Perceptions of Recent Changes in Corporate R\&D, in: Granstrand, O.; Håkanson, L.; Sjölander, S. (Eds.): Technology Management and International Business: Internationalization of $R \& D$ and Technology. Chichester: Wiley, 117-135

Cheng, J. L. C.; Bolon, D. S. (1993): The Management of Multinational R\&D: A Neclected Topic in Journal of International Busines Research, 1, 1-18

Coombs, R.; Richards, A. (1993): Strategic Control of Technology in Diversified Companies with Decentralized R\&D, in: Technology Analysis \& Strategic Management 5, 4, 385-396

Dalton, D. H.; Serapio, M. G. (1995): Globalizing Industrial Research and Development. Washington, D.C.: US Department of Commerce

De Meyer, A. (1992): Management of International R\&D Operations, in: Granstrand, O.; Håkanson, L.; Sjölander, S. (Eds.): Technology Management and International Business: Internationalization of R\&D and Technology. Chichester: Wiley, 163-179

De Meyer, A., Mizushima, A. (1989): Global R\&D Management, in: R\&D-Management 19, 2, 135-146

De Pay, D. (1989): Die Organsation von Innovationen. Die Anwendung des Dekompositionsprinzips von Williamson, in: Albach, H. (Ed.): Organisation. Wiesbaden, 289-313

Domsch, M. (1993): Laufbahnentwicklung für Industrieforscher, in: Domsch, M.; Sabisch, H.; Siemers, S. H. A. (Eds.): F\&E-Management. Stuttgart, 153-178

Gassmann; O. (1997a): Internationales F\&EManagement. München, Wien: Oldenburg

Gassmann; O. (1997b): Organisationsformen internationaler F\&E, in: Zeitschrift für Organisation 6, 332-339

Gassmann; O.; von Zedtwitz, M. (1996): Ein Referenzrahmen für das Internationale Innovationsmanagement, in: Gassmann; O.; von Zedtwitz, M. (Eds.): Internationales Innovationsmanagement. München: Vahlen, 3-15

Gassmann, O.; von Zedtwitz, M. (1998): Towards the Integrated R\&D Network - New Aspects of 
Organizing International R\&D, in: Lefebvre, L.A.; Mason, R.M.; Khalil, T. (1998, Eds.): Management of Technology, Sustainable Development and EcoEfficiency. Amsterdam: Elsevier, 85-99

Gerpott, T.J. (1991): Globales F\&E-Management: Bausteine eines Gesamtkonzepts zur Gestaltung eines weltweiten F\&E-Standortsystems, in: Booz; Allen und Hamilton (Eds.): Integriertes Technologie- und Innovationsmanagement. Berlin, 49-73

Gerpott, T. (1994): Successful integration of R\&D functions after acquisitions: An explorative empirical study, in: $R \& D$ Management 25, 2, 161178

Gerybadze, A.; Meyer-Krahmer, F.; Reger, G. (Ed., 1997): Globales Management von Forschung und Innovation. Stuttgart: Schäffer-Poeschel

Gerybadze, A.; Reger, G. (1997): Globalisation of R\&D: Recent Changes in the Management of Innovation in Transnational Corporations, Working paper 97-01 at University of Hohenheim. Stuttgart

Granstrand, O.; Håkanson, L.; Sjölander, S. (1993): Internationalization of R\&D - a Survey of Some Recent Research, in: Research Policy 22, 413-430

Håkanson, L. (1981): Organization and Evolution of Foreign R\&D in Swedish Multinationals, in: Geografiska Annaler 63 B 1, 47-56

Håkanson, L. (1992): Locational Determinants of Foreign R\&D in Swedish Multinationals, in: Granstrand, O.; Håkanson, L.; Sjölander, S. (Eds.): Technology Management and International Business: Internationalization of $R \& D$ and Technology. Chichester: Wiley, 97-115

Håkanson, L.; Nobel, R. (1993): Determinants of Foreign R\&D in Swedish Multinationals, in: Research Policy 22, 397-411

Håkanson, L.; Zander, U. (1988): International Management of R\&D: The Swedish Experience, in: $R \& D$ Management 18, 3, 217-226

Hicks, D.; Ishizuka, T.; Keen, P.; Sweet, S. (1994): Japanese Corporations, Scientific Research and Globalization, in: Research Policy 23, 375-384

Howells, J. (1990): The Location and Organisation of Research and Development: New Horizons, in: Research Policy 19, 133-146

JPC (Japan Productivity Center/St. Paul Rikkyo University) (1990): Utilization of Foreign Universities and Other Research Institutes by Japanese Corporations

Krubasik, E. G., Schrader, J. (1990): Globale Forschungs- und Entwicklungsaktivitäten, in: Welge, M. K. (Ed.): Globales Management. Stuttgart, 17-27

Kutschker, M. (1989): Akquisition, internationale, in: Macharzina, K.; Welge, M. K. (Eds.): Handwörterbuch: Export und internationale Unternehmung, Col. 2-22

Kuwahara, Y. (1998): Management Practices for Innovation in Global Industrial Research, in: Boutellier, R.; Gassmann, O.; von Zedtwitz, M.
(1998): International Organization of Industrial $R \& D$. Heidelberg, Berlin, New York: Springer, forthcoming

National Science Board (1996): Science \& Engineering Indicators - 1996. Washigton, D.C.: US Government Printing Office, NSB 96-21

NIW, DIW, ISI, ZEW (1995): Zur Technologischen Leistungsfähigkeit Deutschlands. Erweiterte Berichterstattung 1995. Endbericht an das Bundesministerium für Bildung, Wissenschaft, Forschung und Technologie (BMBF). Hannover, Berlin: BMBF

Nonaka, I.; Takeuchi, H. (1995): The KnowledgeCreating Company. New York: Oxford University Press

Papanastassiou, M.; Pearce, R. (1994): The internationalisation of research and development by Japanese enterprises, in: $R \& D$ Management 24, 2, 155-165

Patel, P. (1996): Are large firms internationalizing the generation of technology? Some new evidence, in: IEEE Transactions on Engineering Management, Vol. 43, 1, 41-47

Patel, P.; Pavitt; K. (1992): Large Firms in the Production of the World's Technology: an Important Case of Non-Globalisation, in: Granstrand, O.; Håkanson, L.; Sjölander, S. (1992): Technology Management and International Business: Internationalization of $R \& D$ and Technology. Chichester: Wiley, 53-74

Pearce, R. D.; Singh, S. (1991): The overseas laboratory, in: Casson, M. (Ed.): Global Research Strategy and International Competitiveness. Oxford: Basil Blackwell, 183-212

Pearson, A.; Brockhoff, K.; von Boehmer, A. (1993): Decision Parameters in Global R\&D Management, in: $R \& D$ Management 23, 3, 249-262

Roberts, E.B. (1995): Benchmarking the Strategic Management of Technology I, in: Research Technology Management 38, 1, 44-56

Schoonhoven, C.; Jelinek, M. (1990): Dynamic Tension in Innovative, High Technology Firms: Managing Rapid Technological Change Through Organizational Structure, in: von Glinow, M.; Mohram, S. (Eds.): Managing Complexity in High Technology Organization. New York: Oxford University Press, 90-118

Securities Data Company (1998): Worldwide Mergers \& Acquisitions, in: Neue Zürcher Zeitung (Eds.): Ein steiniger Weg für junge Biotech-Firmen, Dec. 9, 286, 24

von Boehmer, A.; Brockhoff, K.; Pearson, A.W. (1992): The Management of International Research and Development, in: Buckley, P. J.; Brooke, M. Z. (Eds.): International Business Studies, Oxford, 495-509

Wortmann, M. (1990): Multinationals and the Internationalization of R\&D: New Developments in German Companies, in: Research Policy 19, $2,175-183$ 